Indian J. Anim. HIth. (2019), 58(2) : 227-232

DOI: https://doi.org/10.36062/ijah.58.2.2019.227-232

Research Article

\title{
IMPACT OF NUTRISIGMA ${ }^{\circledR}$ ON PERFORMANCE OF YOUNG GAROLE LAMBS
}

\author{
S. SOREN*, B. ROY, P. BISWAS ${ }^{1}$, J. A. GORE ${ }^{2}$ AND A. K. DAS ${ }^{3}$ \\ Department of Animal Nutrition \\ F/o Veterinary and Animal Sciences \\ West Bengal University of Animal and Fishery Sciences \\ 37, K. B. Sarani, Kolkata-700 037, West Bengal, India
}

\begin{abstract}
The aim of the study was to evaluate the effect of "Nutrisigma" ${ }^{\circledR}$ " on performance of young Garole lamb. Eighteen young Garole lambs on an average $4.95 \pm 0.33 \mathrm{~kg}$ body weight were divided into 3 feeding groups (6 Garole lambs each) as per their live weight for $\mathbf{1 0 5}$ days in a growth trial. They were allowed for grazing in the grazing land in the day time and all the treatment groups $\left(C o n t r o l, T_{1}\right.$ and $\left.T_{2}\right)$ were offered $150 \mathrm{gm} / \mathrm{animal} /$ day concentrate mixture. In addition to concentrate mixture $T_{1}$ and $T_{2}$ group was offered $10 \mathrm{~g} / \mathrm{h} / \mathrm{d}$ and $20 \mathrm{~g} / \mathrm{h} / \mathrm{d}$ Nutrisigma@ respectively. Initially up to 75 days of experiment period no significant changes had been observed in the body weight among the groups. Afterwards, on day 90 and day 105 of experiment period significant changes $(P<0.01)$ had been observed in body weight within the treatment groups compared to control group. Economically more feasible were obtained in $T_{1}$ and $T_{2}$ groups compared to control group. Positive body condition score was obtained in treatment groups in comparison to control group. So, it may be concluded that supplementation of Nutrisigma ${ }^{\circledR}$ with concentrate mixture could be used economically up to $20 \mathrm{~g} / \mathrm{head} / \mathrm{day}$ without any harmful effect on growth performance, however; the use of Nutrisigma ${ }^{\circledR} 10 \mathrm{~g} / \mathrm{head} / \mathrm{day}$ is economically more viable for Garole lambs.
\end{abstract}

Key words: Garole lambs, Growth performance, Nutrisigma ${ }^{\circledR}$

The Indian economy is based on agriculture and allied sectors. Rural people largely depend on agriculture which has great impact on small and marginal farmers as well as landless laborers. The sheep and goat are allowed to graze on pastures, wastelands, fallow lands etc. or on stall fed to satisfy their nutritional demand. However due to rapid reduction of grazing lands, urbanization, water scarcity, industrialization, land utilization pattern and non availability of cultivable lands, the gap between availability and requirement of nutrients is increasing. Therefore under the prevailing circumstances exploration of new feed resources become necessary to overcome the problem of feed scarcity. Feed resources like

*Corresponding Author

${ }^{1}$ State livestock Farm, Kalyani, Nadia, WB, India

${ }^{2}$ IFB Agro Industries Ltd. Sector-1, East Kolkata Township, Kolkata 700107

${ }^{3}$ Department of Animal Genetics and Breeding, F/O Veterinary and Animal Science, WBUAFS. Kolkata-700 037 
unconventional feed including agro-industrial by-products and livestock waste either utilized or rarely utilized have a great role providing useful nutrients for existing under nourished livestock population. Bio-Fuel production increased the availability of plant processing by-products, such as dried distiller's grains with soluble (DDGS). DDGS have higher nutritive value and relatively cheaper in cost than other traditional feed ingredients. It is considered as an effective and useful component of concentrate mixtures. It is characterized by high crude protein (about 30\%) content, enriched in higher percentage of ruminal bypass protein (about 55\%) with higher energy value (Schingoethe et al., 2009). It is an attractive source of energy as well as protein for sheep (Schauer et al., 2008). The component of DDGS is an excellent supplement for ruminants consuming low to moderate quality forages (Stock et al., 2000; Spiehs et al., 2002). DDGS can satisfyingly replace the energy and protein value in the concentrate mixture as it contains of higher polyunsaturated fatty acids (PUFA), mainly linoleic acid (C 18:2), it can also change the fatty acid profile of the meat. They can be added in growing or finishing animals and lowering production costs compared with traditional feed ingredients such as sorghum grain and soybean meal (Schauer et al., 2005). Therefore, the use of high amounts of DDGS can be economically justifiable. So, dried distiller's grains with soluble are most widely utilized in sheep nutrition (Schauer et al., 2008; Borzuta et al., 2014). As dried distiller's grains with soluble is most widely used in sheep nutrition that's why 'Nutrisigma ${ }^{\circledR}$ '- a balanced nutrition booster produced by IFB Agro Industries limited, Kolkata is used in this study. Nutrisigma $^{\circledR}$, is developed from rice grain fermentation from ethanol industry. No previous researches with Nutrisigma ${ }^{\circledR}$ on lambs have been reported.

Thus, the objective of this experiment was to find out the effective levels of 'Nutrisigma ${ }^{\circledR}$ ' offered in the ration on growth parameter and body condition scoring (BCS).

\section{MATERIALS AND METHODS}

This study was carried out at Department of Livestock Farm Complex, West Bengal University of Animal and Fishery Sciences, Mohanpur campus, Nadia, West Bengal, India, from February, 19 to May, 19.

\section{Selection and distribution of experimental} lambs: Eighteen young Garole lambs aged 3-4 months old weighing $4.95 \pm 0.33 \mathrm{~kg}$ were selected for conducting a growth trial for a period of 105 days. They were randomly distributed into three experimental groups viz., control, $\mathrm{T}_{1}$ and $\mathrm{T}_{2}$ each having six animals in a complete randomized block design (CRD) such that the initial body weights were almost similar in all groups. Experimental groups were identified with three different colour applied on the body coat. Red, green and blue colour was used for control, $T_{1}$ and $T_{2}$ group, respectively.

Housing and management of experimental animals: The experimental animals of all the three groups were kept under uniform housing throughout the experiment period. They were offered clean and fresh drinking water round the clock. The animals were maintained in a semi intensive system. They were allowed for grazing during day time in the grazing land and returned their respective pen in evening. All the three groups were offered commercial concentrate mixture twice daily at 9:00 hours 
and 16:00 hours, respectively by weighing in electronic balance at the rate of $150 \mathrm{~g} / \mathrm{head} / \mathrm{day}$ for entire experiment period of 105 days. $T_{1}$ group received $10 \mathrm{~g} /$ head/day and $\mathrm{T}_{2}$ group received $20 \mathrm{~g} / \mathrm{head} /$ day 'Nutrisigma ${ }^{\circledR}$, respectively in addition to basal diet. Feed was analyzed for proximate analyses (AOAC, 2000) is presented in Table 1. The composition of Nutrisigma ${ }^{\circledR}$ as per product literature has been presented in Table 2.

\section{Table 1. Chemical composition of} concentrate mixture

\begin{tabular}{lc}
\hline Component & $\begin{array}{c}\text { Percentage on } \\
\text { DM basis }\end{array}$ \\
\hline DM & 90.385 \\
CP & 13.125 \\
EE & 1.1 \\
CF & 16.2 \\
Total ash & 10.7 \\
Acid insoluble ash & 3.13 \\
Ca & 0.855 \\
\hline
\end{tabular}

Table 2. Chemical composition of Nutrisigma $^{\circledR}$

\begin{tabular}{ll}
\hline Component & Per 250 gm \\
\hline Protein & $80 \mathrm{~g}$ \\
Fat & $23 \mathrm{~g}$ \\
Macro \& micro nutrients & $126 \mathrm{~g}$ \\
Vitamin A & $50000 \mathrm{IU}$ \\
Vitamin D3 & $5000 \mathrm{IU}$ \\
Vitamin E & $250 \mathrm{mg}$ \\
\hline
\end{tabular}

Live weight recording: The animals were weighed fifteen days interval using the electronic balance before feeding and watering in the morning. Weights were recorded for two consecutive days and the mean was taken to represent the body weight.

Economic efficiency: The commercial concentrate mixture was procured in reasonable cost. The cost of concentrate mixture was Rs. $30 / \mathrm{kg}$ and Nutrisigma ${ }^{\circledR}$ was Rs. $110 / \mathrm{kg}$. Thus, the total cost of ration was obtained by adding the cost of concentrate mixture along with Nutrisigma ${ }^{\circledR}$ consumed in the entire experimental period (105 days).

The cost of live weight gain per kilogram was obtained by dividing the total cost of concentrate mixture and Nutrisigma ${ }^{\circledR}$ consumed with total body weight gain.

Body condition score (BCS): Body condition scoring of experimental animals was done through visual and tactile evaluation of body fat reserves by using a 5-point scale. Body condition scores (BCS) were an indirect estimate of energy balance. Where through 1 to 5 point was given according to a very thin sheep to excessively fatty sheep and 3 denotes as a healthy sheep. Evaluation performed on the basis of backbone, hip, shoulder, ribs, tail head and body outline of the sheep as described by Michel (2008), is shown in Table 3. To minimize the error the scoring was done by three person panel during sampling. BCS was recorded prior to the experiment followed by fifteen days interval.

Data analysis: The results obtained from the experiment were analyzed by using IBM SPSS version 23 software.

\section{RESULTS}

Growth performance: The results in Table 4 showed that inclusion of Nutrisigma ${ }^{\circledR}$ in lambs ration had no significant effect among the groups up to 75 days of experiment period but the results of 90 days and 105 days of experiment period clearly show that treatment groups $\left(\mathrm{T}_{1}\right.$ and $\left.\mathrm{T}_{2}\right)$ had significant $(\mathrm{P}<0.05)$ effect on body weight in comparison to control group. 
Economic efficiency: The present study indicates that (Table 4) better economic feasibility (cost/kg weight gain) were obtained in $\mathrm{T}_{1}$ (169.94) and $\mathrm{T}_{2}(202.16)$ groups compared to control (210) group. Through the entire experiment requirement of Nutrisigma ${ }^{\circledR}$ were @ $1.05 \mathrm{~kg} / \mathrm{h}$ head $\left(\mathrm{T}_{1}\right)$ and @ $2.1 \mathrm{~kg} / \mathrm{h}$ head $\left(\mathrm{T}_{2}\right)$ and cost were Rs. 115.50 and Rs. 231 in $\mathrm{T}_{1}$ and $\mathrm{T}_{2}$ respectively. Total weight gain after 105 days experimental period were $2.25 \mathrm{~kg}(\mathrm{C}), 3.46 \mathrm{~kg}$ $\left(\mathrm{T}_{1}\right)$ and $3.48 \mathrm{~kg}\left(\mathrm{~T}_{2}\right)$.

Body condition scoring: Average BCS was presented in Table 4. Here, it is clear that initial BCS were almost same. After three and half months of experiment better BCS were

Table 3. Body condition scoring chart for ruminant

\begin{tabular}{|c|c|c|c|c|c|}
\hline Body parts & BCS 1 & BCS 2 & BCS 3 & BCS 4 & BCS 5 \\
\hline Backbone & Prominent & Visible & Visible faintly & Not visible & Not visible \\
\hline $\begin{array}{l}\text { Hips and } \\
\text { shoulder }\end{array}$ & Prominent & Visible & Not visible & Not visible & Fat deposit \\
\hline Ribs & Clearly visible & Visible faintly & Not visible & Well covered & Well covered \\
\hline Tail head & Recessed & $\begin{array}{l}\text { Slightly } \\
\text { recessed }\end{array}$ & Not recessed & Slightly lumpy & Very lumpy \\
\hline Body outline & Skeletal & Bony & $\begin{array}{l}\text { Almost } \\
\text { smooth }\end{array}$ & Rounded & $\begin{array}{l}\text { Bulging due } \\
\text { to fat }\end{array}$ \\
\hline Remarks & Poor & Moderate & Good & Fat & Grossly fat \\
\hline
\end{tabular}

Table 4. Effect of Nutrisigma ${ }^{\circledR}$ on growth performance and economic efficiency of Garole lambs

\begin{tabular}{llllc}
\hline Variable & \multicolumn{1}{c}{$\mathbf{C}$} & \multicolumn{1}{c}{$\mathbf{T}_{\mathbf{1}}$} & \multicolumn{1}{c}{$\mathbf{T}_{\mathbf{2}}$} & P-value \\
\hline Day 0 & $4.95 \pm 0.33$ & $4.88 \pm 0.39$ & $4.93 \pm 0.23$ & 0.99 \\
Day 15 & $5.11 \pm 0.25$ & $5.09 \pm 0.22$ & $5.16 \pm 0.21$ & 0.97 \\
Day 30 & $5.67 \pm 0.25$ & $5.78 \pm 0.32$ & $5.87 \pm 0.14$ & 0.86 \\
Day 45 & $5.75 \pm 0.24$ & $5.89 \pm 0.31$ & $6.07 \pm 0.23$ & 0.69 \\
Day 60 & $6.14 \pm 0.27$ & $6.81 \pm 0.38$ & $6.97 \pm 0.14$ & 0.13 \\
Day 75 & $6.84 \pm 0.44$ & $7.53 \pm 0.41$ & $7.66 \pm 0.16$ & 0.26 \\
Day 90 & $7.17 \pm 0.25^{\mathrm{b}}$ & $8.32 \pm 0.30^{\mathrm{a}}$ & $8.49 \pm 0.26^{\mathrm{a}}$ & $0.01^{* *}$ \\
Day 105 & $7.20 \pm 0.31^{\mathrm{b}}$ & $8.34 \pm 0.24^{\mathrm{a}}$ & $8.41 \pm 0.27^{\mathrm{a}}$ & $0.01^{* *}$ \\
Final weight gain & 2.25 & 3.46 & 3.48 & - \\
Feed cost & 472.50 & 472.50 & 472.50 & - \\
Nutrisigma & - & 115.50 & 231.00 & - \\
Total cost & 472.50 & 588.00 & 703.50 & - \\
Cost/ kg of gain & 210.00 & 169.94 & 202.16 & - \\
Initial BCS & 2.70 & 2.65 & 2.68 & - \\
Final BCS & 2.72 & 3.20 & 3.10 & \\
\hline
\end{tabular}

** $\mathrm{P}<0.01$, Means with different superscripts in the same row differ significantly

Prices (Rs.): Feed- 30/kg, Nutrisigma ${ }^{\circledR}-110 / \mathrm{kg}$ 
observed in $\mathrm{T}_{1}$ (from 2.65 to 3.20 ) and $\mathrm{T}_{2}$ (from 2.68 to 3.10 ) but there was no such improvement shows in case of control group (from 2.7 to 2.72).

\section{DISSCUSSION}

Growth performance: In this experiment it was observed that in initial phase, upto 75 days growth performance had no significant $(\mathrm{P}>0.05)$ changes among the treatment groups. But there was clear significant changes $(\mathrm{P}<0.05)$ in performance of the treatment groups and better results were observed due to supplementation of Nutrisigma ${ }^{\circledR}$ after 90 days of the study. All the animals were maintained under grazing condition, only little amount of feed was offered to the animal. The treatment groups were allowed additional supplementation of Nutrisigma ${ }^{\circledR}$ which is the rice based DDGS. DDGS is an ideal supplement for ruminants consuming low to moderate quality forages (Stock et al., 2000). It is an attractive source of energy as well as protein for sheep (Schauer et al., 2008). The present studies confirmed with the studies of Avila stagno et al. (2013) reported that a better body weight was obtained in lamb with $40 \%$ wheat DDGS as comparison to basal diet.

Yossifov et al. (2012) also reported that, final body weight gain were significantly affected by DDGS $(\mathrm{P}<0.001)$ included diets in lambs.

Economic efficiency: Better economic feasibility was obtained in treatment groups compared to control group in present experiment. This is due to additional supplementation of Nutrisigma ${ }^{\circledR}$. As control group did not receive Nutrisigma ${ }^{\circledR}$ as a result the feed cost was much less than the $T_{1}$ and $T_{2}$. Total weight gain was reverse to the feed cost.
Here better weight gain was observed in treatment groups than the control group. Hence better economic feasibility was observed in the $\mathrm{T}_{1}$ group compared to $\mathrm{T}_{2}$ and control group. Similar result was found by McEachern et al. (2009) who reported that DDGS can reduce feed cost $/ \mathrm{kg}$ of gain.

Body condition scoring: The result of present study shows that supplementation of 'Nutrisigma ${ }^{\circledR}$ ' has positive effect on BCS. Positive BCS changes recorded in this study can be attributed mainly due to the nutrient content of Nutrisigma ${ }^{\circledR}$ which is rich in bypass protein, bypass fat, vitamins and mineral nutrients.

In short, Nutrisigma ${ }^{\circledR}$ is a balanced nutritive booster fortified with bypass protein, bypass fat and fat soluble vitamins in significant quality, with high calcium and phosphorous content with micronutrients. In present study Nutrisigma ${ }^{\circledR}$ was used in growing Garole lamb. Though total weight gain is almost similar in treatment groups but cost per kg weight gain is much better in $\mathrm{T}_{1}$ group as because the cost of Nutrisigma $^{\circledR}$ used in each animal is half in $\mathrm{T}_{1}$ $(10 \mathrm{~g} / \mathrm{head} /$ day $)$ group as compared to $\mathrm{T}_{2}(20$ $\mathrm{g} /$ head/day) group.

So, it may be concluded that supplementation of Nutrisigma ${ }^{\circledR} 10 \mathrm{~g} / \mathrm{head} /$ day is economically viable for Garole lambs.

Conflict of interest: Authors declare that there is no conflict of interest regarding the present research work.

\section{ACKNOWLEDGEMENT}

The help from M/s. IFB Agro Industries limited, Kolkata, for supply of Nutrisigma ${ }^{\circledR}$ for the entire research period is duly acknowledged. 


\section{REFERENCES}

AOAC, 2000. Official Methods of Analysis. 17 $7^{\text {th }}$ edn., Association of Official Analytical Chemists. Washington, DC, USA

Avila-stagno J, Chaves AV, Graham AS and McAllister TA, 2013. Effects of replacing barley grain with wheat distillers grains on growth performance, eating behaviour and subcutaneous fatty acid profiles of lambs. Acta Agric Scand A Anim Sci, 63(2): 93100

Borzuta K, Borys B, Lisiak D, Grzeœkowiak E, Janiszewski P et al., 2014. Quality of meat, fatty acid profile, and slaughter value of lambs intesively fed feed supplemented with biofuel co-products. Food Sci Technol Qual, 6: $113-124$

McEachern JK, Whitney TR, Scott CB, Lupton CJ and Salisbury MW, 2009. Substituting distillers dried grains for cottonseed meal in lamb-finishing diets: growth, wool characteristics, serum NEFA, Urea N, and IGF- 1 concentrations. Sheep Goat Res J, 24: $32-40$

Michel W, 2008. Body Condition Score. http:// dairynutrient. wisc.edu/302/page.php?id=36
Schauer CS, Anderson LP, Stecher DM, Pearson D and Drolc D, 2005. Influence of dried distillers grains on feedlot performance and carcass characteristics of finishing lambs. Western Dakota Sheep Beef Day, 46: 31-33

Schauer CS, Stamm MM, Maddock TD and Berg $\mathrm{PB}, 2008$. Feeding of DDGS in lamb rations. Sheep Goat Res J, 23: 15-19

Schingoethe DJ, Kalscheur KF, Hippen AR and Garcia AD, 2009. Invited review: the use of distillers products in dairy cattle diets. $\mathbf{J}$ Dairy Sci, 92: 5802-5813

Spiehs MJ, Whitney MH and Shurson GC, 2002. Nutrient database for DDGS produced from new ethanol plants in Minnesota and South Dakota. Anim Sci, 80: 2639-2645

Stock RA, Lewis JM, Klopfenstein TJ and Milton CT, 2000. Review of new information on the use of wet and dry milling feed by-products in feedlot diets, University of Nebraska Lincoln 68583, Faculty Papers and Publications in Animal Science Paper 555.

Yossifov M, Kozelov L and Dimova K, 2012. Effect of dried distillers grains with soluble from corn DDGS fed on fattening lambs. Agric Sci Tech, 4(3): 223-227 